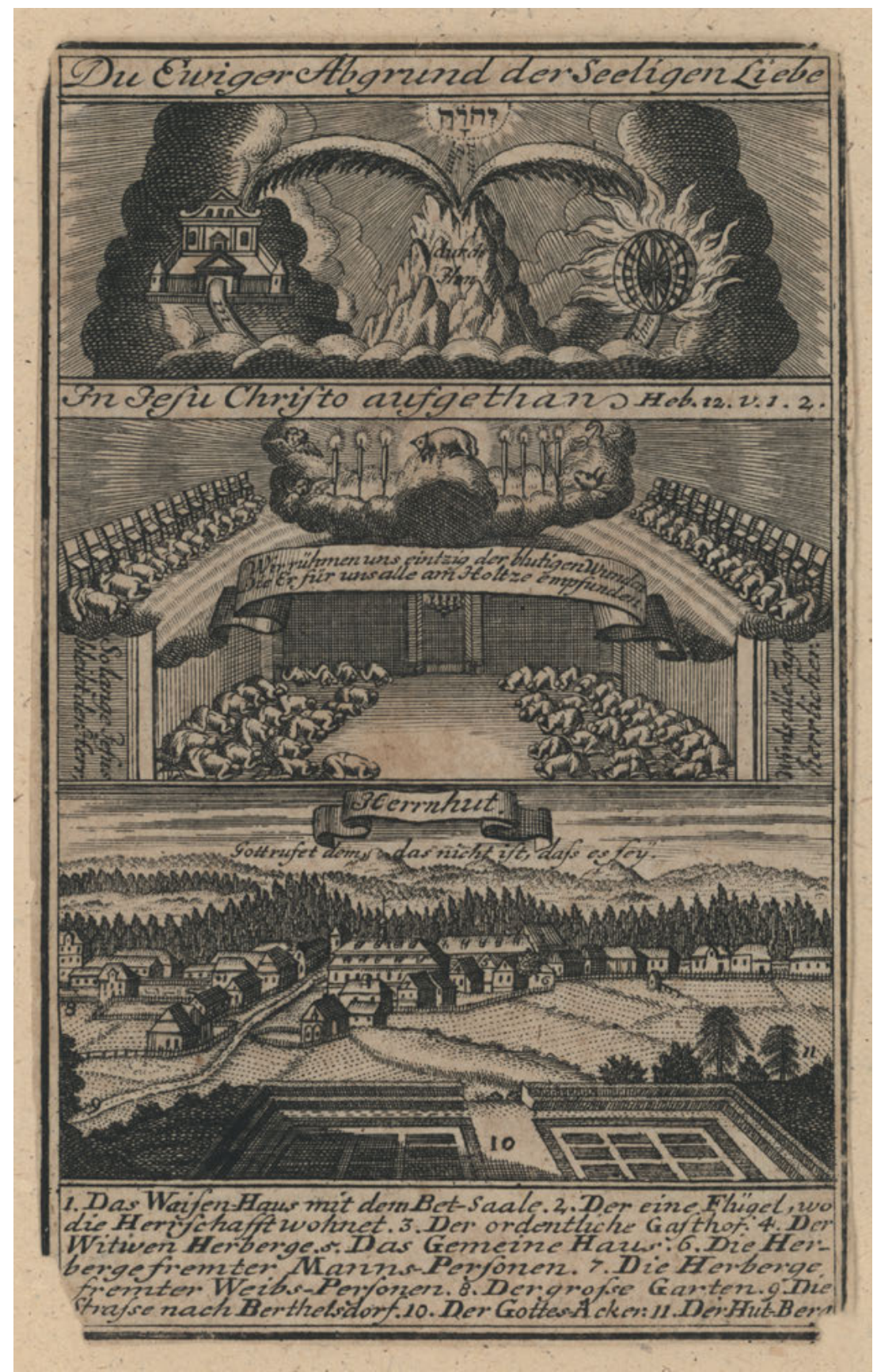

Fig. 4.1: "Du ewiger Abgrund der Seeligen Liebe in Jesu Christo aufgethan Hebr 12:1.2." Frontispiece of Christian David's Beschreibung und Zuverläßige Nachricht von Herrnhut (Leipzig, 1735). Copper engraving.

Ә Open Access. (c) 2021 Elisabeth Engell Jessen, published by De Gruyter. (c) BY-NC-ND This work is licensed under the Creative Commons Attribution-NonCommercial-NoDerivatives 4.0 International License. https://doi.org/10.1515/9783110639476-005 


\section{Citizens in Christ: Moravian Women, Art, and Presence}

Eighteenth-century Moravians often set up communities in newly built settlements, for example Christiansfeld in Southern Denmark, which became a power centre for Scandinavian Moravians. This article explores in which way Christiansfeld relates to the idea of the New Jerusalem and how life took place in Christiansfeld. In particular, I discuss the role of art, writing, and self-expression amongst women, men, and children in the Moravian communities, arguing that community members used selfexpression as a way of establishing an ideal Christian community of believers. Through writing, singing, playing music, and engaging with art, they found ways of entering Christ's body, communally as well as individually, thus setting up a spiritual New Jerusalem within.

In a 1735 engraving from a publication by Christian David (1692-1751), a prominent Moravian, we see three scenes arranged in vertical sequence, all relating to communal, urban life (Fig. 4.1). At the bottom (a) is a depiction of Herrnhut, the center of Moravian spirituality and administration, and in the middle (b), we see the Moravian congregation prostrate in the Hall, worshipping the Lamb ( $\operatorname{Rev} 5) .{ }^{1}$ At the top (c) we see the eternal kingdom or the New Jerusalem, with the Temple on the left and Ezekiel's wheels on the right (Ezek 1; 40). ${ }^{2}$ The three scenes appear to be connected: the artist uses symmetry and order to tie the images together, and the heavenly hills above visually echo the hills surrounding Herrnhut. As the scenes are arranged vertically, the viewer gets the impression that all three locations are present or available at the same time. The collective worship depicted in the middle (b) takes place in Herrnhut (a), the central or "holy" urban locus of the Moravian Gemeine (although not an exclusive locus, since Herrnhut here seems to represent every Moravian settlement or society, where worship takes place). The collective worship in turn leads each believer, as well as the community as a whole, upwards (c) towards the New Jerusalem, which represents the end of salvation history, the place where each believer is heading. The three locations are thus present at the same time, and each believer can move between them now:

1 A Moravian church is usually known as a Saal [Hall].

2 Hans-Cristoph Hahn and Hellmut Riedel, eds., Zinzendorf und die Herrnhuter Brüder. Quellen zur Geschichte der Brüder-Unität von 1722 bis 1760 (Hamburg: Wittig, 1977), 179.

Elisabeth Engell Jessen, PhD, Minister, Danish Lutheran Church, Aarslev, Denmark 
moving towards heaven is possible every day, if one participates in communal, Moravian worship.

In this perspective, the transformation from being a citizen of the earth to being a citizen of heaven becomes a question of space rather than a question of time. At the same time, however, the engraving also illustrates the linear journey of every believer from a state of sin to being a man of God, a journey that according to the Moravians was not completed until after death. ${ }^{3}$ The two perspectives, the linear "one day" and the spatial "now," are thus present in the image at the same time, both underlining the Moravian idea of movement. For the eighteenth-century Moravian storyworld is characterized by the idea of settlement and home, and the idea of moving, spiritually as well as physically; Moravians may have built towns across the globe, but they often moved between them. And they settled down for a while, but only did so knowing that their true homes were somewhere else. They were first and foremost world citizens (Weltbürger), not Germans, Danes, or Englishmen, and their home was the whole world (for now) and, one day, heaven. ${ }^{4}$

The engraving shows how Moravians, like many other Christians, used the concept of the New Jerusalem to illustrate where they were heading in a spiritual sense. But, at the same time, eighteenth-century Moravians seem to have been more occupied with the idea of belonging and finding rest in Christ's body (becoming citizens in Christ) than in building a New Jerusalem, either in Jerusalem or elsewhere. ${ }^{5}$ It is this dichotomy that forms the base of this chapter, in which I am interested in how Christ's body as a location takes over some of the characteristics of divine urban space, and how the "storyworld" of salvation history was constructed in the Moravian community (and especially how art plays into that construction). I discuss how Christ's body, and not so much the idea of the New Jerusalem, comes to represent "home" and "rest" for each believer; a living, breathing space in which each believer could set up home and lead a normal, Christian, urban life.

Thus, it does not seem to be the case that eighteenth- and nineteenth-century Moravians ignore the metaphor of Jerusalem or the New Jerusalem as such, but they rather take the metaphor of divine urban living to a new level, where the heavenly city is understood as Christ himself. This is interesting, seeing that they took great care

3 See Gisela Mettele, "Constructions of the Religious Self: Moravian Conversion and Transatlantic Communication," Journal of Moravian History no. 2 (Spring 2007), 2, 7-36.

4 Gisela Mettele, “Eine 'Imagined Community' jenseits der Nation. Die Herrnhuter Brüdergemeneine als transnationale Gemeinschaft," Geschicte und Gesellschaft 32, no. 1 (2006), 45-68.

5 This more literal expression of the wish to realise the New Jerusalem here and now was prominent in other religious contexts, in particular amongst British radical forces. One (of several) examples of groups attempting to build the New Jerusalem in England was the Panacea Society, a religious group beginning to set up the New Jerusalem in Bedford in the early twentieth century, but with inspiration from Joanna Southcott (1750-1814), a popular prophet from Devonshire. The society still exists. See Jane Shaw, Octavia, Daughter of God: The Story of a Female Messiah and her Followers (New Haven and London: Yale University Press, 2011). 
building their settlements as ideal, urban spaces for their community, i.e. something that easily lends itself to being understood as a New Jerusalem. Thus, when I started to look into the history of Christiansfeld, the power centre of Moravian life in Scandinavia in the eighteenth and nineteenth century, I expected to find a plethora of references to Jerusalem. As a newly built urban complex in which believers could realize life en Christo ("in Christ") within a communal setting, the settlers here had a unique opportunity to envision an ideal setting for their community and, as it were, build their own New Jerusalem. But this seems to have been implied rather than articulated directly, although there are clear markers in the town plan revealing that Christiansfeld is indeed God's urban space, for example the cross shape that divides the central square into four smaller squares with a well in the centre (the well had a practical function as well as a spiritual, symbolic meaning). ${ }^{6}$ I thus came across fewer direct references to Jerusalem/the New Jerusalem in the Moravian material than I expected. Instead, I found indirect references to Christiansfeld as Jerusalem (or "Israel”), such as when Hans Caspar Brandt, a Danish nineteenth-century businessman - who did not live in Christiansfeld and was therefore always longing for it - wrote a letter to the community, and signed it "Your lowly brother in Egypt,"7 thereby positioning himself as resident in a place removed from the Holy Land (and, by implication, its centre Jerusalem).

However, what seems to be a paucity of references to Jerusalem in the Moravian material does not mean that Moravians were unaware of connections between their newly built towns/settlements and the idea of the New Jerusalem. When the first house was finished in the settlement that was to become Herrnhut, for example, Count Nicolaus Zinzendorf's (1700-1760) steward Heitz gave a speech on Revelation 21, in which he "spoke of the magnificence of the New Jerusalem, of the holiness and happiness of its inhabitants, applying these ideas to the house they had erected."8 But with the Moravians, the idea of Jerusalem as the urban locus or destination of salvation (collectively as well as individually) seems to have been taken over by the

6 Jørgen Bøytler and Jørgen Toft Jessen, Christiansfeld. Livet og Husene, 2nd ed. (Kolding: Det Danske Idéselskab, 2015), 196.

7 "Fra din ringe Broder i Egybten," ["from your lowly brother in Egypt"] in Jens Holdt, "Breve fra Hans Caspar Brandt i Svendborg til Christiansfeld,” in Kirkehistoriske Samlinger, sjette række, fjerde bind (København: Selskabet for Danmark Kirkehistorie, Gads Forlag, 1942-1944), 143. Brandt's letters are an interesting source for exploring non-resident Moravians' relationship with, and experience of, the community in Christiansfeld. Brandt's primary reason (or excuse) for frequently communicating with the Christiansfeld society was that his children attended school there.

8 Ami Bost, History of the Moravians (London: Religious Tract Society, 1862), 162. The scene also appears in Hutton where the speech is described as "a sort of prophetic sermon about the holy city, the new Jerusalem coming down from God out of heaven"; J. E. Hutton, A History of the Moravian Church (London: Moravian Publication Office, 1909), 199. Nikolaus Ludwig von Zinzendorf was the leader of the Moravians until his death in 1760. It was on his estate that refugees from Moravia and descendants of the Bohemian Brethren settled in 1722. Zinzendorf himself was educated in Pietist Halle. 
body of Christ, a spatial image that may have been better suited for the Gemeine as a movable, transnational network of believers. Thus Christiansfeld seems to have been conceived not as the New Jerusalem of the Nordic countries, but as a new Herrnhut ( $c f$. the two Moravian settlements in Greenland and on Saint Thomas that were actually called Neu-Herrnhut).

Obviously, the relationship between the idea of the historical Jerusalem vis-à-vis the New Jerusalem is complex, as the two loci are intimately connected yet separate. I will not go further into that discussion here, but only note that eighteenth-century Moravians generally seem more invested in the idea of the New Jerusalem than in Jerusalem as an actual, historical place. However, they did - like many others - travel to Jerusalem, and in 1865 they founded a "leper home" known as Jesushilfe outside the Jaffa Gate. After the Second World War, the Israeli government took over the home and the Moravians instead set up Sternberg in Ramallah, which was closed in 1979. ${ }^{9}$ There was also traffic going the other way, from Jerusalem to Europe, for in a diary by Inga Kahr, a Norwegian girl attending school in Christiansfeld from 1867 to 1870, we read about "the beautiful Sophie Vallentiner" who was "the blondest of all": "none could have guessed [she] was born in Jerusalem."

\section{Christiansfeld}

Christiansfeld is situated between Haderslev and Kolding in Southern Jutland and was founded in 1772. Now beautifully restored, it was built on the initiative of the Danish King Christian VII (r. 1766-1808), whom had visited Zeist, a Moravian town in Holland, in 1768 and been impressed by the order and industry there. The king made his minister of finance, Carl August Struensee, approach the Moravian authorities in Herrnhut and enquire whether the Moravians would be interested in settling in Denmark. Building began in 1773 and by 1780, most of the houses that still constitute the centre of Christiansfeld were finished. As a special gesture, and to boost local business, the king admitted the Moravians in Christiansfeld certain privileges, such as tax exemption for the first ten years, and in return, the town was named after him. ${ }^{11}$

9 Paul Peucker, Lanie Graf and Markus Gill, "Moravian Work in Jerusalem," This Month in Moravian History, no. 9 (2006). Accessed September 12, 2018, http://moravianchurcharchives.org/thismonth/ 06_july_jerusalem.pdf.

10 Quoted in Annemette Løkke Borg Berg, Lene Lindberg Marcussen and Karen Stoklund, eds., Danish World Heritage Nomination: Christiansfeld a Moravian Settlement I \& II (Kolding Municipality, 2014), 137. I am grateful to Eivor Andersen Oftestad for drawing my attention to this, and to Käte Thomsen from the Moravian Archive in Christiansfeld for digging out the correct reference.

11 Bøytler and Jessen, Christiansfeld. Livet og Husene, 20-39, and Anders Pontoppidan Thyssen "Det store og det lille herrnhutersamfund," in Herrnhuter-samfundet i Christiansfeld, ed. Anders Pontoppidan Thyssen (Åbenrå: Historisk Samfund for Sønderjylland, 1984), 42-3. 
Christiansfeld was built on Langager, a field that originally belonged to the farm Tyrstrupgård. The town was characterized by order and simplicity and it was similar to other Moravian towns, in particular Herrnhaag in Wetterau. The buildings were, and still are, elegant and spacious, the roads straight, and the layout simple: the town was structured around two parallel streets, Lindegade and Nørregade, with a centre consisting of the square with the well and the Hall along on the western side of the square. Gardens were also incorporated into the town plan and the Moravian town builders retained the beautiful views from the town towards the fields, emphasizing the fact that Christiansfeld was situated within a landscape, not separate from it. Even today, looking west from Lindegade, one still gets a strong sense of the interplay between urban and rural. The inhabitants of Christiansfeld did not, however, primarily work the land, for apart from a love of gardening that they shared with many other Moravians, they were craftspeople: they manufactured ceramic stoves (and still do); they were cobblers, carpenters, or butchers; they produced textiles and baked goods, or worked in the tobacco factory; only to mention some of the trades. As a result, the town was industrious and grew quickly, just as the king had hoped. ${ }^{12}$

Christiansfeld quickly became the centre of Moravian life and spirituality in Scandinavia, with people of Moravian observance, like Hans Caspar Brandt, visiting Christiansfeld whenever possible and sending their children - girls as well as boys - to the town's Moravian schools (until 1810 especially from Sweden, and later, from 1832, especially from Norway; the Norwegian writer Camilla Collett, for example, was educated in Christiansfeld). ${ }^{13}$ And even though there were Moravian societies elsewhere - in Denmark most notably in Copenhagen (where Søren Kierkegaard's father was an active member) and in Skjern in Western Jutland Christiansfeld remained the only Moravian settlement in Scandinavia and thus played a special role. (Usually, members did not practice communal living in the societies, only in the settlements. $)^{14}$

12 Bøytler and Jessen, Christiansfeld. Livet og Husene, 34-9. For a list of trades 1789-1810, see Thomas Bloch Ravn, "Håndværk og fabriksvirksomhed," in Herrnhuter-samfundet i Christiansfeld, ed. Anders Pontoppidan Thyssen (Åbenrå: Historisk Samfund for Sønderjylland, 1984), 174.

13 Thomas Bloch Ravn, "Kostskolerne," in Herrnhuter-samfundet i Christiansfeld, ed. Anders Pontoppidan Thyssen (Åbenrå: Historisk Samfund for Sønderjylland, 1984), 519; Thomas Bloch Ravn and Anders Pontoppidan Thyssen, "Kostskolernes Opblomstring," in Hermhuter-samfundet i Christiansfeld, ed. Anders Pontoppidan Thyssen (Åbenrå: Historisk Samfund for Sønderjylland, 1984), 551.

14 For more on Moravians outside Christiansfeld in eighteenth-century Denmark, see Anders Pontoppidan Thyssen, ed., Vækkelsernes Frembrud i Danmark i første Halvdel af det 19. Århundrede (Institut for Dansk Kirkehistorie, 1960-1977), in particular vols. 1, 3, 4, and 5. 


\section{Moravian Life: Uniformity and Communication ${ }^{15}$}

Moravian towns are usually easily recognisable, due to the global character of the congregation (Moravians from early on preferred the term "congregation," Gemeine, to "church," emphasizing that they were not interested in forming a new church, but instead sought to facilitate Christians practicing their faith in a new way). ${ }^{16}$ Moravian craftsmen in particular, but also other community members, often moved between towns, bringing knowledge, skills, habits, and taste with them, so that crafts from Christiansfeld, for example, were often considered "German" in style by other people in Denmark. ${ }^{17}$ For community members, though, the idea was not to be national, but rather transnational: they ought to "immer mehr Wehrt auf die Ehre (legen), Bürger des Reiches Gottes zu sein" [constantly (place) more value on the honour of being a Citizen of the Kingdom of God], as a choir report (see below) from Christiansfeld 1809 puts it. ${ }^{18}$ Thus, they were not primarily citizens of Christiansfeld, but citizens of God's (invisible) Kingdom.

The idea of uniformity was also expressed in the way people dressed (women, for example, wore ribbons indicating their marital status), and by the fact that each local congregation was divided into so-called "choirs" based on gender and marital status. But it perhaps found its most distilled expression in the Moravian burial place, the "God's acre” [Gudsageren] where all gravestones were, and still are, simple, identical stones with no indication of social status or status within the community. Here, members were buried according to gender and time of death, not alongside their families.

Town plans were always discussed with Herrnhut before building commenced, and the plans were afterwards kept in the extensive Unity Archives in Herrnhut. Thus, Christiansfeld might have been built from scratch on a field in Southern Jutland, but the buildings and layout of the town were not, as it were, drawn out of thin air. Instead, they were meant to recall or replicate a model of Christian, communal living that had already proved successful elsewhere in Europe and North America. A similar strategy was used in the Moravian mission fields, but it soon proved difficult to replicate a lifestyle developed on a wealthy estate in pietistic Europe in, say, Sumatra or Greenland.

15 It is Vogt who has pointed towards uniformity and communication as fundamental principles in eighteenth-century Moravianism. Peter Vogt, "A Voice for Themselves: Women as Participants in Congregational Discourse in the Eighteenth-Century Moravian Movement," in Women Preachers and Prophets through Two Millenia of Christianity, eds. Beverley Mayne Kienzle and Pamela Walker (Berkeley, London: University of California Press, 1998).

16 Vogt, "A Voice for Themselves," 243.

17 Ravn, "Håndværk og fabriksvirksomhed," 190, 256.

18 Quoted in Mettele, “Eine 'Imagined Community' jenseits der Nation,” 51. 
The administration in Herrnhut also (often) decided when to move community members, and where, such as when the organ player in Christiansfeld, Johan Herman Mankell, was relocated to Sweden due to leading what was perceived as a scandalous life. ${ }^{19}$ But they also valued moving between communities and did so voluntarily. There was a strong culture of constant movement and communication, the importance of which was evident in the continuous stream of letters and Gemeinnachrichten [community newsletters] that circulated between members. ${ }^{20}$ Thomas Christensen, for example, was born near Christiansfeld in 1756, moved to Zeist and then, later, via Hamburg and London, relocated to work in the mission in Labrador. Returning from Labrador, he landed in Gravesend, went to the Moravian settlement Fulneck in West Yorkshire, and from there, via London and Altona, went back to Christiansfeld where he died in $1821 .^{21}$ Typically, Thomas Christensen's life story was communicated to other community members in the Gemeinnachrichten, the editors of which often took care in choosing Lebensläufe (spiritual autobiographies) that might be particularly interesting when read aloud in the local communities on the first Monday in each month. ${ }^{22}$ Also, the value that Moravians placed on communication between local communities is evident in the constant distribution of things and objects that would ensure, for example, a suitably Moravian (or European) life style in the Moravian colonies. ${ }^{23}$ So women in Christiansfeld slept in dormitories, dressed uniformly, and wrote letters to similarly dressed Moravian women in Herrnhut, whom also slept in dormitories and wrote letters.

The very fact that writing - the act of shaping experience through personal expression - was encouraged (to the extent that every Moravian was expected to write their own Lebenslauf) shows that although uniformity was valued, it did not follow from there that individual experience or expression was devalued. Rather, the two existed alongside each other, the individual expression seemingly flourishing within the framework (or restraints) of communal uniformity. The Lebensläufe were, on one hand, narratively and structurally guided by the Lebenslauf genre and therefore often similar in tone, structure, and spiritual vocabulary; as Gisela Mettele has put it, "the only taboo was to provide a narrative that did not lead towards salvation but rather to estrangement from the community." 24 But they were also individual in that they recounted individual lives and did so by taking each Moravian seriously as an authorial

\footnotetext{
19 Sybille Reventlow, "Musik og Sang," in Herrnhuter-samfundet $i$ Christiansfeld, ed. Anders Pontoppidan Thyssen (Åbenrå: Historisk Samfund for Sønderjylland, 1984), 678-9.

20 For an illustration of how Moravians were often born in one Moravian community and died in another, see moravianlives.org.

21 "Lebenslauf der Bruders Thomas Christensen" in Nachrichten 1823: 477-84. Thomas Christensen was in Labrador from 1798 to 1816.

22 Mettele, “Constructions of the Religious Self," 18-9.

23 I am grateful to Jessica Cronshagen for pointing this out.

24 Mettele, “Constructions of the Religious Self," 23.
} 
voice (although if someone died before finishing the autobiography, it was finished by others). The Lebensläufe are in some ways very uniform, and this uniformity might sometimes puzzle modern readers. But the very fact that they are there, that they are there in such abundance, and that they have been kept in the Moravian archives, testifies to the importance that the community as a whole placed on the idea of the individual within the community. Female Moravians expressed themselves - and were expected to express themselves - through the Lebenslaüfe, as well as through other literary genres such as hymns. In combination with the Moravian emphasis on creative self-expression through art and music, which I discuss below, these female Moravians turned into literary voices that used their own lives as creative bases; sometimes even combining literary genres, and, for example, composing a hymn to be included in the Lebenslauf. ${ }^{25}$ Or, to put it differently, they created something new that was intended not (only) for private use or as a private, spiritual exercise, but also was given a place in the public sphere; for the Lebenslauf was read aloud at every community member's funeral.

\section{Moravian Women in Christiansfeld}

Thus the world of the Moravian women in Christiansfeld might, from one perspective, seem constrained, but they wrote, they worked, they travelled, and they were in contact with other communities through correspondence and visits: in particular, the Christiansfeld sisters had connections with Zeist, Gnadau, Neuwied, Neudietendorf, Neusalz, Herrnhut, Gnadenfeld, Niesky, Gnadenfrei, Surinam, and Greenland. ${ }^{26}$ The women also served one another in pastoral roles, for the renewed Moravian church paid more attention to the role of women than many other religious communities. Zinzendorf, in particular, seems to have been sensitive to the potential of women taking up roles that were traditionally assigned to men. In 1745, Zinzendorf ordained 20 women as deaconesses, and in 1758 he ordained three female presbyters and 18 deaconesses, as well as declaring that he had also ordained presbyters, or "priestesses," in the past, but had kept it quiet in order to avoid scandal. For Zinzendorf, "the whole band, the whole company, the whole choir of his maidens and brides, are priestesses,

25 Johanna Bitterlich, for example, included a 12-stanza song that she had composed herself in her Lebenslauf (Mettele, "Constructions of the Religious Self,” 34). For extracts of women's Lebensläufe from Christiansfeld, see Anne-Marie Mai, “'To be deeply moved in one's inner being': Examples of Memoirs written by Moravian Women," In Nordic Light, eds. Thomas Bredsdorff, Søren Peter Hansen and Anne-Marie Mai (Odense: Syddansk Universitetsforlag, 2007). See also, for example, Katharine M. Faull, Moravian Women's Memoirs: Their Related Lives, 1750-1820 (Syracuse: Syracuse University Press, 1997).

26 Tove Elklit, "Befolkning og fattigforsog," in Herrnhuter-samfundet i Christiansfeld, ed. Anders Pontoppidan Thyssen (Åbenrå: Historisk Samfund for Sønderjylland, 1984), 123. 
and not only priestesses but also priestly women."27 Despite the fact that ordained women were only allowed to carry out pastoral duties towards other women, the mere fact that they were allowed is extraordinary. And although Zinzendorf's death in $\mathbf{1 7 6 0}$ meant that leading forces within the Gemeine immediately revoked some of the female privileges, women continued to play an active role in Moravian communities. Thus, female deaconesses (but not presbyters) were ordained until 1790, but after that, it was not until 1967 that the next woman was ordained. ${ }^{28}$

In Christiansfeld, the large and centrally placed Sisters' House testifies to the care that was given to the sisters' living, assembling, and working quarters. As in many other Moravian towns, the Sisters' House was understood as particularly important, ${ }^{29}$ and women consistently outnumbered men in the Christiansfeld community between 1803 and 1860; in 1835, as much as 61 per cent of the congregation were women. This was probably at least partly due to immigration patterns, as female Moravians who moved to Christiansfeld came to settle down, whereas male Moravians often left after a period of time. ${ }^{30}$ Compared with the neighbouring town of Haderslev, Christiansfeld also had a larger percentage of elderly women, fewer children, and people, if they married, tended to marry late in life. ${ }^{31}$

Moravian women were divided into the unmarried (i.e. "not yet married") choir, the married sisters' choir, and the widows' choir. Girls were in the Girls' Choir until their confirmation, after which they joined the Sisters' Choir, and later they moved into the Sisters' House. ${ }^{32}$ Until the end of the nineteenth century, the

27 Vogt, “A Voice for Themselves,” 229.

28 In the eighteenth century, there were also female acolytes, who were not ordained, whereas deacon (esses), presbyters, and bishops were all ordained (there were no female bishops): Paul Peucker, Lanie Graf, Thomas J. McCullogh and Markus Gill, "Women Priests in the Moravian Church in 1758," This Month in Moravian History, no. 31 (2008). Accessed September 20, 2018, http://www.moravianchurch archives.org/thismonth/08\%20may\%20women\%20priests.pdf. See also Beverly Prior Smaby, “'Only Brothers should be accepted into this proposed council': Restricting Women's Leadership in Moravian Bethlehem," in Pietism in Germany and in North America 1680-1820, eds. Jonathan Strom, Hartmut Lehmann and James Van Horn Melton (Farnham, Burlington: Ashgate Publishing Limited, 2009) and Vogt, "A Voice for Themselves,.”

29 Bøytler and Jessen, Christiansfeld. Livet og Husene, 85.

30 Tove Elklit, "Befolkning og fattigforsog," in Herrnhuter-samfundet i Christiansfeld, ed. Anders Pontoppidan Thyssen (Åbenrå: Historisk Samfund for Sønderjylland, 1984), 107. Neighbouring towns Haderslev, Husum, and Tønder also had a majority of women in the period (slightly above 50 per cent), but significantly less than Christiansfeld's almost 60 per cent between 1803 and 1845. Although women are usually a slight majority, 61 percent is quite a high number, according to Elklit.

31 Elklit, "Befolkning og fattigforsog," 108-110. The community grew quickly after its foundation in 1773, and in 1813 it consisted of 652 people. After that, numbers declined (Elklit, "Befolkning og fattigforsog," 105-6.) Not everyone in town belonged to the congregation, with 94 per cent of its inhabitants being Moravian in 1803 decreasing to 63 per cent in 1860 .

32 Bøytler and Jessen, Christiansfeld. Livet og Husene, 78. 


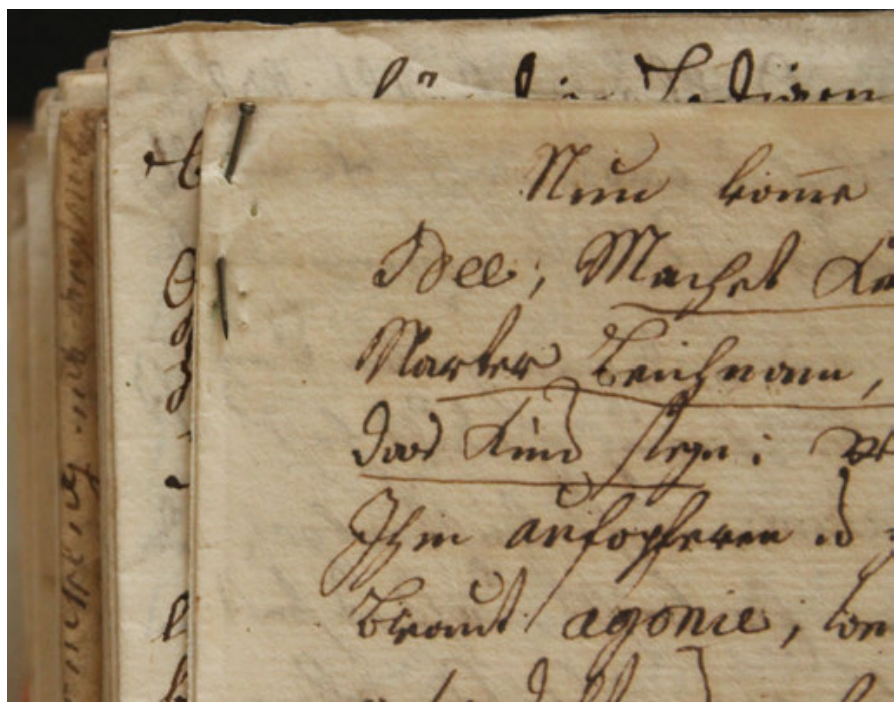

Fig. 4.2: A choir speech with pages held together by a sewing pin, from S.A.I.R.5.a. Korreden and S.A.I.R.5.b. Korreden, Moravian archive, Christiansfeld.

Sisters' House was where women slept (in large dormitories), and where they ate, worked, and sold their crafts in the shop. ${ }^{33}$ The sisters gathered in the large, firstfloor hall for daily worship and Singstunden [Singing Time, liturgical hymn singing], accompanied from around 1778 by their own organ, as well as by other instruments, such as the harp. ${ }^{34}$ The hall is spacious, and it is easy to imagine how the white walls and natural light from the windows, softened by white curtains, would create an ideal atmosphere to focus on Christ. The Moravian sisters were renowned for being musical, and the girls were taught music and singing in school, but the women's concerts remained closed for outsiders, as they played for their own joy and spiritual benefit, not for others. ${ }^{35}$ They also wrote choir speeches and read them aloud here. The speeches are still kept in the Sister's Archive and testify to the life and subject matters of early Christiansfelder Moravians in Denmark. There are speeches on Christmas and on mission, for example, written out in German and later in Danish, that sometimes show traces of having been written in a large, communal house buzzing with various activities: one speech is held together by what was clearly at hand - a sewing pin (Fig. 4.2). ${ }^{36}$

33 Bøytler and Jessen, Christiansfeld. Livet og Husene, 79.

34 Reventlow, "Musik og Sang,” 634, 659.

35 See Reventlow, "Musik og Sang," 695-98. The musical archive in Christiansfeld is extensive.

36 The speeches are found in S.A.I.R.5.a. Korreden and S.A.I.R.5.b. Korreden in the Moravian archive in Christiansfeld. 


\section{Restlessness, Longing, and Setting up Home in Jesus' Body}

The Moravian focus on music being fundamental for the formation of every single believer, as well as for the spiritual wellbeing of the congregation as a whole, points to the vibrant cultural life that took place in Moravian communities. For as quiet and orderly as eighteenth- and nineteenth-century Moravians might seem, music, art, and poetry were seen as vital parts of life; expressing the idea that in a Moravian community, members sought to live in constant, joyful, communal worship ("joy" being a keyword in the Moravian alphabet of faith). As such, the Christian minimalism we encounter today in Christiansfeld is a little deceptive. In fact, we might even say that the beautiful restoration of Christiansfeld's buildings is misleading in terms of reflecting life in an eighteenthand nineteenth-century Moravian town, as it enhances only one part of life there.

The restoration pays tribute to tradition, workmanship, stone, and solid shapes; to straight lines and houses built in good quality materials that are meant to last. In this, however, the dynamic spirit of Moravian communities easily escapes us: that centrifugal and almost impatient force that drove eighteenth-century believers restlessly forward, building lasting structures in stone, yet at the same time distancing themselves from that which they created and focusing on that which is to come: the Kingdom of God. ${ }^{37}$ Eighteenth-century Moravians lived within a spiritual framework where every material thing, as well as every human action, had spiritual value - a deeply liturgical understanding of life; the grounds of which was Christ as the incarnated divine being. As Christ participated in every part of human life, he made every human action potentially holy, and thus all of human life (and not just that which took place in the Hall) was considered liturgy; even sleeping and waking from sleep. ${ }^{38}$

The human being gradually becomes used to performing all activities with dignity - sweeping, washing houses, whatever one wants to name and whatever presents itself, from the largest to the smallest and most despicable routine - and thereby the likeness of Jesus shines through and nothing is lost. That is liturgical. ${ }^{39}$

But, although everything is liturgy and, in a sense, holy, the believer is always en route, spiritually speaking. This dynamic, restless perspective is what we see represented in Moravian mission work, which was integral to the Gemeine's self-understanding, and

37 This restlessness is well captured in Per Olov Enquist's novel Lewis Resa [Lewis' Journey] (2001): a description of the Evangelical movement in Sweden in the twentieth century, which also includes descriptions of Christiansfeld.

38 Hahn and Riedel, Zinzendorf und die Herrnhuter Brüder. Quellen zur Geschichte der Brüder-Unit ät von 1722 bis 1760, 213-4.

39 Jüngerhausdiarium, April 20, 1760, quoted in Mettele, "Constructions of the Religious Self," 12. 
in the so-called Streiter [fighter] spirit in the Moravian societies. ${ }^{40}$ We also see the dynamic perspective in Moravian piety, for example in hymns, which were written by women as well as men..$^{41}$ Here, the author often expresses a wish to be elsewhere; a longing for unity with Christ, or, to speak in Jerusalem terms, to move from "the earthly Jerusalem" in the metaphorical sense of the term (for example a Moravian town in Southern Jutland) to the heavenly Jerusalem. Zinzendorf, for example - who was a keen and exceptionally productive hymn writer - typically expresses this spatial longing as walking in "the land of shadows" and "walking together in the footsteps of Jesus," asking Jesus to "lead us to our true home." 42 This true home is not a lovely Moravian town below, but rather the eternal Gemeine above.

Interestingly, though, for a community that was so keen on building, this spatial longing is often not described in urban terms. Instead, eighteenth-century Moravian piety refers to a shared landscape of salvation that is grounded in Christ's body. The geography of his wounded body dictates, to a large extent, the language that eighteenth-century Moravians experience the world with and express themselves in. It is, to simplify a bit, more a question of Paul's en Christo rather than Ezekiel's or Revelation's vision of the New Jerusalem. ${ }^{43}$

The believer longs to be housed in the side wound nourished and protected by the blood, and to set up home in Christ's body - not in a building made of stone, but of living, breathing body. In this body, the restless soul can finally find the much longed for peace, as illustrated in a striking devotional card from Herrnhut

40 Thyssen, “Det store og det lille herrnhutersamfund," 24-5.

41 In the 1740s, Moravian women and men participated in the Poeten-Liebesmahl, a version of the special Moravian service Liebesmahl (Love Feast), an agape inspired occasion at which tea and rolls were (and still are) served. In Poeten-Liebesmahle, women and men competed in hymn writing (Vogt, "A Voice for Themselves," 237). Many hymns by female Moravian writers were later incorporated into Moravian hymn books, including the ones used in Christiansfeld (see more in Reventlow, "Musik og Sang”). Louise von Hayn (1724-1782), for example, was a notable Moravian hymn writer. She was leader of the single-sisters' choir in Herrnhut from 1766, and fourteen of her hymns appeared in the 1767 hymn book. In the 1778 hymn book, the number was 44 (whole or in part) (Paul Peucker, Lanie Graf, Thomas J. McCullogh and Markus Gill, "Henriette Maria Louise von Hayn," This Month in Moravian History, no. 22 (2007). Accessed October 3, 2018, http://www.moravianchurcharchives.org/ documents/07aug.pdf; see also Elisabeth Schneider-Böklen ““Amen, ja, mein Glück ist groß.' Henriette Louise von Hayn (1724-1782) - eine Dichterin des Herrnhuter Pietismus” (PhD diss., University of Marburg, 2005).

42 "Jesus, gå foran” in Tillæg af Salmer og Liturgier for Brødremenigheden i Christiansfeld [Additional Hymns and Liturgies for the Moravian Society in Christiansfeld] 2007: 104-5. My translation.

43 For more on the idea of Christ's body in relation to the Moravian understanding of community, see Christina Petterson, "Imagining the Body of Christ," in Sexuality, Ideology and the Bible: Antipodean Engagements, eds. Robert J. Myles and Caroline Blyth (Sheffield: Sheffield Phoenix Press, 2015), 35-55. 
where we see Christ's side wound containing a bed and a satisfied Moravian fast asleep. The side wound or side hole, referring to the Roman soldier's lance piercing Jesus' body on the cross in John 19:32, was probably the most popular trope amongst mid-eighteenth-century Moravians, and according to Craig Atwood, it continued to be used until the end of the eighteenth century. ${ }^{44}$ It was used to describe a place where each longing believer - in this connection acting primarily as an individual - could find rest, peace, and spiritual nourishment. "Soft wounds of Jesus. I like lying calm, gently, and quiet and warm. What should I do? I crawl to you," Zinzendorf put it in his Wundenlitanei [Litany of the Wounds] from around $1744 .{ }^{45}$

Other similar devotional cards, often in deep red and green colours, further explore the metaphor of "the home in the divine body," adding more features to it and almost building an eternal town within the divine body. Thus, in one card we have the side hole containing a house, and in another, the imaginative devotion-card painter(s) cum city planner(s), from Herrnhut, adds a fountain and a park to the landscape. The description of that which happens within Christ's body as something civilized, almost urban, is emphasized in the accompanying short texts: "I am asleep in the side hole, do not wake my noble soul," reads the card with the sleeping Moravian. Others read, "There [in the side hole] I enjoy all the delicatessen" and "I go for a walk in the side hole" (this is found on the image showing the park and a fountain). ${ }^{46}$ None of these activities described in words are, of course, exclusively urban, but together with the urban imagery in the cards they create an enticing and colourful urban dream of life lived as a citizen in Christ's body. Here, members of the Moravian society that from the beginning had defined themselves as religious refugees, as homeless, as pilgrims, could finally find rest in a town that was also a body. ${ }^{47}$

44 There is a plethora of studies of Moravian usuage of the side hole or side wound. See for example Craig D. Atwood, "Little Side Holes: Moravian Devotional Cards of the Mid-Eighteenth Century," Journal of Moravian History, no. 6 (2009): 61-75 (for more on the history of the devotional cards); and Craig D. Atwood, “Zinzendorf's Litany of the Wounds,” Lutheran Quarterly, no. 11 (1997): 188-214 (for an example of how the trope was used in literature/liturgy). There is an ongoing discussion as to the relationship between the so-called Sifting Time (a scandalous period in the 1750s) and the figurative language surrounding blood, wounds, and holes. For a recent and thorough discussion, see Paul Peucker, A Time of Sifting: Mystical Marriage and the Crisis of Moravian Piety in the Eighteenth Century (University Park: Penn State University Press, 2015).

45 Quoted in Atwood, "Zinzendorf's Litany of the Wounds," 208.

46 Quoted in Atwood, "Little Side Holes," 62.

47 "Die Erfahrung der Heimatlosigkeit hatte sich der Brüdergemeine gewissermaßen von Anbeginn ins Bewusstsein eingeschrieben" [The experience of homelessness (lit. homeland-ness) had, as it were, entered Moravian consciousness from the very beginning] Mettele, "Constructions of the Religious Self," 52. 


\section{Moravian Art}

If we take a closer look at eighteenth-century Moravian art, we also see the double perspective of expectation and realization, of waiting for Christ and assuming that he is already present in the midst of the congregation. ${ }^{48}$ The Moravians were fond of images, portraits of community members, biblical scenes, and graphic illustrations of Christ on the cross, to the extent of being accused of being "popish." ${ }^{49}$ A key point in their philosophy of art was the almost literal idea of the presence of the depicted: an image of Christ worked not so much as a representation of Christ, but to ensure his presence in the room, at that moment. Likewise, a portrait of a community member like Zinzendorf could be used to make him present locally, for example when celebrating his birthday.

The art collection in Herrnhut consists of almost 300 oil paintings, mostly portraits, ${ }^{50}$ but we do not see much art on display in Christiansfeld today. There is a copy of Thorvaldsen's statue of the risen Christ (known from Vor Frue Kirke, the cathedral, in Copenhagen; see Fig. 11.0) above the liturgical table in the Hall, and in the choir hall in the Sisters' House, we see an oil painting of the risen Christ, likewise situated above the liturgical table. ${ }^{51}$ However, oil paintings also in a sense belong to the "static" sphere of Moravian life, in that they were created to last: they were framed and displayed (sometimes, though, Moravian missionaries would bring paintings with them in order to display them to "the heathens," hoping that the language of art would communicate what faltering language skills could not). ${ }^{52}$ But in eighteenth-century Moravian communities, we would probably have come across just as much art belonging to the "dynamic" sphere of life as to the "static" sphere: art that

48 In 1744, the community in Herrnhut pronounced Jesus the main elder of their Gemeine and entered his name into the list of members, complete with details such as birthplace, "Bethlehem," and occupation, "carpenter"; Paul Peucker, "Kreuzbilder und Wundenmalerei. Form und Funktion der Malkunst in der Herrnhuter Brüdergemeine um 1750," Unitas Fratrum, Zeitschrift für Geschichte und Gegenwartsfragen der Brüdergemeine 55/56 (2004), 131. A lot of research has already been done on Moravian music, whereas only very little has been done on Moravian use of art. In this section, I am particularly indebted to Paul Peucker's, "Kreuzbilder und Wundenmalerei" and Paul Peucker's, "A Painter of Christ's Wounds: Johann Langguth's Birthday Poem for Johann Jakob Müller, 1744," in The Distinctiveness of Moravian Culture, eds. Craig Atwood and Peter Vogt (Nazareth: Moravian Historical Society, 2003).

49 Peucker, "Kreuzbilder und Wundenmalerei," 170.

50 Peucker, "Kreuzbilder und Wundenmalerei," and Peucker, "A Painter of Christ's Wounds." Many of the earlier depictions of Christ have vanished.

51 Some objects are also exhibited in the Moravian museum in Christiansfeld.

52 Paul Peucker, "Communication through Art: The Role of Art in Moravian Communities," in Self, Community, World: Moravian Education in a Transatlantic World, eds. Heikki Lempa and Paul Peucker (Bethlehem: Lehigh University Press, 2010), 247. 
was created for a particular occasion, often in haste, and later destroyed, such as festival banners with illustrations to be used in liturgy, or various tableaux. ${ }^{53}$

One example is the 1795 picture from the Girls' School in Bethlehem (Pennsylvania), showing girls singing. They are accompanied by a man (perhaps a music teacher), and above them, a banner shows the first verse from Psalm 115, chosen for 24 March 1795: "Not to us, Lord, not to us but to your name be the glory, because of your love and faithfulness." 54 The garland of flowers that surrounds the Bible verse are replicated in the flowers that surround the image itself, thereby suggesting that the musical girls might speak to us in a similar way as Psalm 115 speaks to the girls.

This argument draws on the expansive Moravian understanding of preaching, according to which other forms of preaching exist alongside, or even perhaps above, the traditional sermon (which, we may note, soon became separate from the liturgy in Moravian communities): we have the "preaching in songs" that the Singstunde represent, or the "preaching through art" that Moravian painters practised. ${ }^{55}$ For Zinzendorf, the crucial point was not that preaching was learned or intellectual. On the contrary: the more affective the preaching, the better, and since songs, paintings, music, and poetry speak to the heart in a more direct and effective way than a scholarly exposition, they were to be valued accordingly. ${ }^{56}$ Likewise, choir members were not meant to gradually understand more and more about Christ, but, as Gisela Mettele puts it, "by means of constant training of the imagination and the feelings, to empathize ever more deeply with the 'life, suffering, and death' of Jesus, in order 'to share in the likeness of Jesus in body and spirit.",57 This anti-intellectual stance is perhaps most memorably reflected in an engraving from around 1750, now in the Unity Archives in Herrnhut, of a man whose head had been replaced by a side wound, illustrating that he had left rational thinking behind and allowed himself to be consumed by faith. ${ }^{58}$

53 The dichotomy between "static" and "dynamic" should by no means be taken too far, but is only meant as a tool to help us think about the origins and use of different types of art and writing. In poetry, for example, Peucker points out that occasional verses often made it into printed hymnals with only minor corrections (Peucker, “A Painter of Christ's Wounds,” 19.) The Moravians in Christiansfeld probably also did this. The archive contains clean copies of various occasional songs, verses, and choir responses, especially to be used at the Singstunde that often accompanied a funeral. A folder in the Prediger-archiv in Christiansfeld (P.A.II.R.11 A.1.g) simply contains various hymns and songs on loose leaves, mostly copied out in neat handwriting.

54 Inscribed on the banner: "Nicht uns HERR nicht uns, sondern deinem Namen gib Ehre um deine Gnade und Wahrheit." The music teachers were not always men. (Trans. New International Version.)

55 See Peucker, “A Painter of Christ's Wounds," and Peucker "Kreuzbilder und Wundenmalerei."

56 For more on the Moravian idea of preaching, see Vogt, “A Voice for Themselves.”

57 Mettele, “Constructions of the Religious Self," 13.

58 Peucker, A Time of Sifting, 70-1, including a reproduction of the image. 

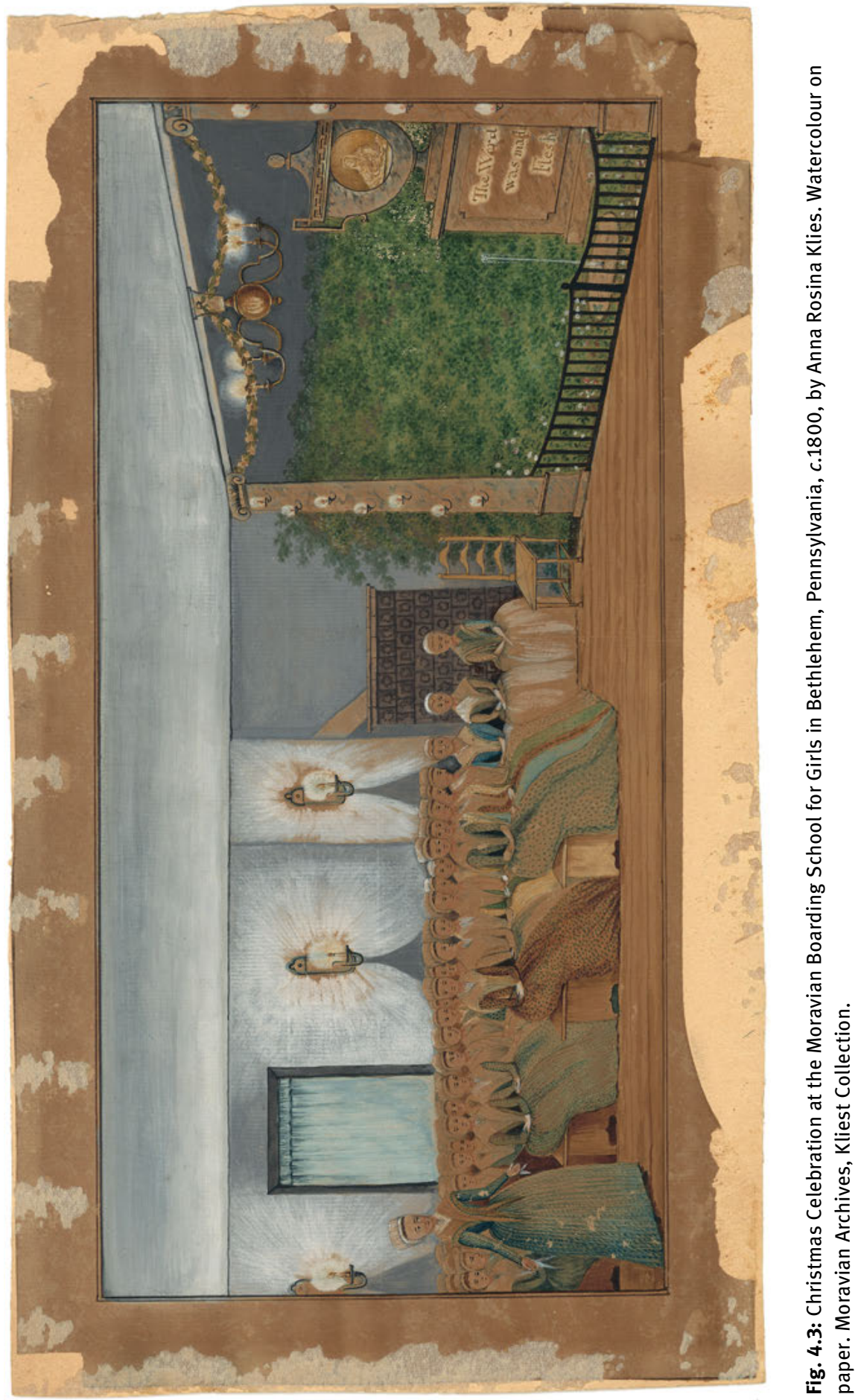
Since all members of the Moravian community were expected to have inner religious experiences and feelings, they were also - painter, baker, and builder alike - expected to be able to share this, with spiritual authority, in a communal setting. Women and men were asked to communicate with each other about life in faith, not simply to listen to a person talking to them, as Zinzendorf put it in 1755: "not merely pious talks were given but conversations to the heart and soul of the members which were coming out of an inner experience." ${ }^{59}$ Or, as the English poet and painter William Blake (1757-1827), who most probably was influenced by the Moravians, articulated it: “A Poet a Painter a Musician an Architect: the Man/ Or Woman who is not one of these is not a Christian ... The unproductive Man is not a Christian." ${ }^{60}$ Moravians were not only expected to experience faith, but also to express it. Their individual experiences were understood as having value within a communal setting.

Another example of Moravian occasional art is an image from Christmas time at the Bethlehem girls' school around 1790 (Fig. 4.3). The image is complicated, in that it is not only a representation of something, but a representation of a representation. ${ }^{61}$ We see a rather large tableau in green, blue, and gold, illuminated by several small lights on the right side of the image (Moravians were fond of illumination), and on the left side we see the girls seated in front of the tableau. The tableau itself seems to consist of a large urn with an image, which is hard to make out, at its centre: it could be Christ as the Lamb. The urn is placed on a stand, on which we read "The Word was made Flesh," and in front of the urn is a simple fountain, similar to the central well that we find on the central square in Christiansfeld. The perspective in the tableau is slightly tweaked so the words on the stand can be clearly read by the viewer. Similarly, the girls all have their heads turned towards the viewer, thereby creating a connection between us and them, inviting us to join them in enjoying the Christmas tableau. Between the girls and the tableau is an empty chair, but it is unclear to whom it belongs: to the teacher who stands on the far-left side of the image (perhaps the artist behind the image, Anna Rosina Kliest, who taught in the school from 1788 to 1805)? To the viewer? Or to Christ himself, being considered part of the congregation; the chief elder of the society?

We also notice how, in the image, the Christmas tableau almost becomes part of the room itself: it is not raised on a platform, but it is available for the girls to stretch

59 Vogt, “A Voice for Themselves," 236. My italics.

60 Laocoön (1826-1827), in David V. Erdman, ed., The Complete Poetry and Prose of William Blake, Newly Revised Edition (New York: Anchor Book, 1988), 274. For more on Blake and the British Moravians, see for example Keri Davies and Marsha Keith Schuchard, "Recovering the Lost Moravian History of William Blake's Family," Blake. An Illustrated Quarterly 38 (2002); and Craig D. Atwood, "Christ and the Bridal Bed: 18th century Moravian Erotic Spirituality as a Possible Influence on Blake," in Re-envisioning Blake, eds. Mark Crosby, Troy Paternaude and Angus Whitehead (Hampshire: Palgrave Macmillan, 2012).

61 I am grateful to Victor Plahte Tschudi for articulating this. 
out and reach if they stand up; only protected by a very low rail. A similar lack of boundary between art work and surroundings is found elsewhere in Moravian art works, for example in festival banners, where blue sky can disappear into the air instead of being stopped by a border. ${ }^{62}$ In fact, the trees from the tableau seem to connect the girls with the tableau, combining the two spheres with a bridge of living leaves. Thus, we get the impression that what is depicted in the tableau also takes place, albeit only for a short while, within the community of the girls. In that sense, it has presence and reality - and, in that sense, it is liturgy.

It is probable that tableaux and illuminations like this have also existed in the girls' school in Christiansfeld. Illumination, for example, was a much-loved activity that also took place in Christiansfeld and it still forms a significant part of the Christmas celebration. We know that "remains of wall decorations," probably referring to occasional art works for liturgical use, exist in Christiansfeld. ${ }^{63}$ Many art works, however, and especially occasional art works and ephemera (as opposed to oil paintings and buildings) have probably disappeared, in Christiansfeld as well as elsewhere. This is partly due to natural causes (fire or mould) and to negligence or disinterest, but also simply to the fact that occasional art works had already served their purpose, so there was no reason to keep them. Instead, they might be disposed of or reused; festival banners, for example, could be painted over with new images and text as to suit the new liturgical occasion or festival. ${ }^{64}$

\section{A Liturgical and Artistic Life}

The subject of Moravian girls and women expressing themselves through art is still a relatively unexplored area. Women wrote their Lebensläufe, they performed as musicians, and were taught to play and sing from an early age, and they were keen hymns writers. We also know that girls were taught painting and drawing, and a large collection of drawings from the girls' school is still kept in the archives in Christiansfeld. ${ }^{65}$ A skilled English female painter, Maria Spilsbury (1776-1820), had strong Moravian links and was daughter of Jonathan Spilsbury (1737-1812), a Moravian engraver who probably knew William Blake. ${ }^{66}$

We also assume that the girls from the school in Bethlehem were involved in creating the Christmas tableau themselves: Maria Rosina Unger notes in her diary that the

62 See Peucker, "Kreuzbilder und Wundenmalerei," 164-6.

63 Ravn and Thyssen, "Kostskolernes Opblomstring," 576.

64 Peucker, "Communication through Art," 259.

65 Ravn and Thyssen, "Kostskolernes Opblomstring," 561.

66 See Keri Davies, "Jonathan Spilsbury and the Lost Moravian History of William Blake's Family," Blake. An Illustrated Quarterly 40, no. 3 (2006/2007). 
girls have been painting for several days as well as collecting "moss \& greens for Christmas." ${ }^{67}$ A diary from a Swedish girl, Clara Rebecca Bager, who attended the girls' school in Christiansfeld from 1835 to 1838 gives the same impression. On the day of the Single Sister's Festival on May 4, 1836, Clara describes that "the previous day we had dressed a room with greens and glasses with flowers."68 Likewise, Inga Kahr, the Norwegian girl in Christiansfeld whose diary I quoted above, notes that the girls themselves decorated their house with garlands of flowers on festival days. ${ }^{69}$

This adds a whole layer to the interpretation of the Christmas tableau and the pictorial representation of it, since the tableau already, in a sense, belonged to the girls, as they had created it. ${ }^{70}$ They were not only taught drawing and music as skills similar to reading and calculating, but they were also trained in using these skills in their joyful life en Christo, to create art installations and then to participate in them and respond to them. The communal life they were expected to participate in was, as it were, a sort of global, Christian Gesammtkunstwerk. However, the tableaux and art installations have now disappeared, and the lasting works of art, for example oil paintings, are often unsigned. Typically, we do not even have the names of the architects that dreamed up Christiansfeld, so the voices - in art, music, and poetry - are there, sometimes even distinctly so, but they are often anonymous.

The idea of liturgisch leben, "living a liturgical life," perhaps addresses this view of Christian life as a work of art. ${ }^{71}$ When living the liturgical life, liturgy, as mentioned above, is not confined to the consecrated room, but is weaved into every little activity, night and day. Within this framework of understanding, praying and singing is liturgy, but so is sleeping, eating, working in the factory, conversing with another community member, and drawing in school. Similarly, the divine reality or the experience of Christ is not only present in church, but in every aspect of life. Moravians not only worshipped Christ as the Saviour, but also commemorated the life of Jesus in detail, so that one could fully dwell upon the fact that Jesus was also a child, a man who ate, drank, and wept, and a carpenter who used his skills. This dwelling on the life of Jesus was expressed in a litany used in Christiansfeld:

67 Unger's diary is transcribed and available online at BDHP Journals, "A JOURNAL kept at BETHLEHEM BOARDING SCHOOL begun in December, 1789 by MARIA ROSINA UNGER," accessed May 9, 2019, http://bdhp.moravian.edu/personal_papers/journals/unger/mariarosina. htmlhttp://bdhp.moravian.edu/personal_papers/journals/unger/mariarosina.html.

68 Ravn and Thyssen, "Kostskolernes Opblomstring," 554. My translation.

69 Inga Kahr, diary from Christiansfeld 1867-1870. Quoted in Berg, Marcussen and Stoklund, Danish World Heritage Nomination, 137.

70 It also draws lines to ideas about the place and use of nature and natural elements within Moravian urban piety: including the use of flowers and plants in women's needlework as well as the idea of the garden as an essential part of a Moravian town; forming a living, colourful, and slightly uncontrollable counterbalance to the balance and permanence of the buildings.

71 Helge Rønnow, "Liturgien," in Herrnhuter-samfundet i Christiansfeld, ed. Anders Pontoppidan Thyssen (Åbenrå: Historisk Samfund for Sønderjylland, 1984), 712. 


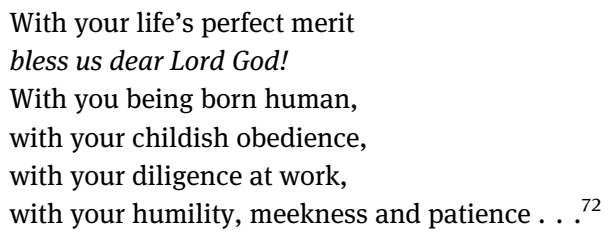

This expresses an impression of Jesus as someone who is also, in a sense, a perfect Moravian: he is human, he is "childish" (a positive term, as Moravians placed particular spiritual value on the child-like state and on children), ${ }^{73}$ and he is obedient, hardworking, humble, meek, and patient. He also, being someone who is "at work," invokes the impression of a citizen - someone who could be living in a Moravian town like Christiansfeld - and a simple man; not a university educated philosopher. He is one of them and, at the same time, the locus that they are all waiting to enter through his wounds. He is someone that they can relate to now, and, at the time, the spatial location that will one day be realized: A New Jerusalem in body and spirit.

Eighteenth- and nineteenth-century Moravian piety placed immense spiritual value on the incarnation. This informed the way they lived; informed liturgy and theology, social structure and education. But it also informed the way they understood art and each believer's responsibility to transform experience into expression. This (often) individual practice - to compose a text, a painting, or a piece of music - then fed back into a collective space, when, for example, a text was read aloud and could stir certain feelings or experiences in others. ${ }^{74}$

The idea of the holy materiality of all things also informed the way the Moravians lived. They settled in ideal towns where town plan and architecture were thought to best facilitate what they understood as true Christian life. As such, they lived a life that could easily be understood as a simplistic attempt to realize life in the New Jerusalem. But they were more subtle in their construction of an urban salvation space: they created a vision of a living body (Christ), in which life as a good, Christian citizen could be lived. Christ's body thus came to represent the New Jerusalem; a large,

72 My translation. Quoted in Rønnow, "Liturgien,” 713. This seems to be a shorter version of The Great Church Litany, the longer version of which also, for example, mentioned Jesus's circumcision: "By thy human birth and circumcision." (Quoted in E. de Schweinitz, The Moravian Manual: containing an account of the Protestant Church of the Moravian United Brethren or Unitas Fratrum (Philadelphia: Lindsay \& Blakiston, 1859), 138.

73 Colin Podmore, The Moravian Church in England, 1728-1760 (Oxford: Oxford University Press, 1998), $132-4$.

74 "During the reading aloud of the biography of the blessed sister, Luise von Hayn, which made a deep impression on me, some things became clear to me through the Holy Spirit, and my heart was so seized that I again sought out solitude and renewed my bond with the Savior amidst tears of love and shame." (Biography of Johann Heinrich Jahr, 1839, quoted in Mettele, "Constructions of the Religious Self,” 20.) For more on von Hayn, see above, fn. 41. 
all-encompassing space that could contain all human life; a transnational Raum [space] in which all Christians - female and male, children and adults - could become true citizens. With Jesus being fully human, so could every Moravian make use of her or his practical skills in a community such as Christiansfeld, and use these practical skills help to build the new, urban reality in the body of Christ: a city of believers that was at the same time an industrious town in Southern Jutland, a congregation united in joyful worship, and a living, breathing city situated in Christ's wounded and resurrected body. Just like in the threefold engraving from Herrnhut. 
